\title{
Peru's Participatory Budgeting: Configurations of Power, Opportunities for Change
}

\author{
M.A. Hordijk \\ Amsterdam Institute for Metropolitan and International Development Studies, University of Amsterdam, The \\ Netherlands
}

\begin{abstract}
In 2003, Peru adopted the "Framework Law on participatory budgeting". It requires all the municipal and regional governments to institutionalize a yearly "participatory budgeting process". The Peruvian Participatory Budgeting (PB) is inspired on the PB-experiment in Porto Alegre, Brazil, but differs on a number of important principles of design. Building on the existing evaluations of the Peruvian nation-wide implementation of PB (2003-2007), this article addresses both the pitfalls and the transformative potential of Peruvian PB. It does so by contrasting the Peruvian PB with $\mathrm{PB}$ in Porto Alegre along the four dimensions on which transformation has been recorded in Porto Alegre: (1) citizens, (2) civil society, (3) the state and (4) civil society - state relations.
\end{abstract}

\section{INTRODUCTION: PARTICIPATORY BUDGETING AND ITS SPREAD}

Participatory Budgeting (PB) is "en vogue". Since the "Orcamento Participativo" (Participatory Budget) from Porto Alegre (Brazil) has been awarded recognition as "best practice in urban management" during the Habitat II conference in 1996, participatory budgeting has been spreading around the world in different varieties. Cabannes [1] estimated that at least 1000 out of Latin America's 16.000 municipalities have introduced participatory budgeting. Recently published case-studies on civic participation in sub-national budgeting show that experiments with Participatory Budgeting are becoming wide-spread, ranging from countries as wide apart as Bangladesh, Russia, South Africa, The Philippines, India, Thailand and the Ukraine [2] to over 100 municipalities in seven European countries [3].

The crux of participatory budgeting is that ordinary people through a deliberative process in a number of meetings discuss and decide over how (a part of) the budget of a municipality, province, region or even state is spent, and subsequently monitor how the selected projects and programmes are implemented. Participatory budgeting thus should be understood as "a process by which citizens, either as individuals or through civic associations, may voluntarily and regularly participate in the decision-making over at least part of a public budget through an annual series of scheduled meetings with government authorities" (p.92) [4]. We should explicitly distinguish PB from other budget-related participatory processes such as participatory expenditure tracking, independent budget analysis, or the vaguer "public participation in budget-making". Although these practices might be valuable in their own right, the actual decision-

*Address correspondence to this author at the Amsterdam Institute for Metropolitan and International Development Studies, University of Amsterdam, Room G. 2.151018 VZ Amsterdam The Netherlands; Tel +31-20-5254058; Fax +31-20-5254051; E-mails: m.a.hordijk@gmail.com, M.A.Hordijk@uva.nl making power over (a part of) the budget is crucial for the transformative potential of participatory budgeting.

Although academic analyses of PB abound, most analyses concentrate on the case of Porto Alegre [5-12] or to a lesser extent - on other Brazilian cases, most notably Belo Horizonte, Recife and Santo André as successful cases [13-18]. Both case-studies and comparative analyses of PBexperiments from outside Brazil are sorely lacking ${ }^{1}$. In this article we will attempt to address this void by analysing the implementation of PB in Peru. Peru is a special case because it is the only country where the formulation of an Integral Development Plan and a budget in a participatory manner at regional, provincial and municipal ${ }^{2}$ levels is mandated by national law. First experiments with Participatory Budgeting started in 2000. The "Framework Law on Participatory Budgeting" was adopted in 2003, and its implementation gradually spread in the years thereafter. In most of Peru's over 2000 regional and municipal governments the implementation of Participatory Budgeting is now in its $5^{\text {th }}$ or $6^{\text {th }}$ round. PB-experiences need time to mature; some scholars have correctly warned that a meaningful assessment of PBs impact can only be undertaken after circa 8-10 years, or two government terms [18]. In the current article we will, hence, not attempt to provide an impact assessment; rather we will attempt to interpret the trends that can be discerned in the implementation of $\mathrm{PB}$ in $\mathrm{Peru}^{3}$. We will do so by contrasting the origins and PB-rules and regulations as

\footnotetext{
Cabannes'[19] comparative analysis of 25 cases, Chavez's [20] comparative analysis of Montevideo and Porto Alegre and Goldfrank's comparative analysis of Montevideo, Caracas and Porto Alegre [21] and his comparative analysis of 14 non-Brazilian cases [4] being notable examples. ${ }^{2}$ Administratively Peru is divided in 25 regions (until the promulgation of the new Law on Decentralization in 2002 labelled "departments"), 195 provinces and 1831 municipal districts. Governments for all these tiers are democratically elected.

${ }^{3}$ This article is based on a number of interviews with key-informants at national and local level in 2 Limenean districts between 2002-2006; participatory action research undertaken between 2002 and 2004 at local level (Lima Metropolitana and two Limenean municipal districts), analysis of the database of the Ministry of Finance (2005-2007) and secondary materials, particularly evaluation studies.
} 
developed in Peru with its source of inspiration: the Orcamento Participativo from Porto Alegre, which is also the case on which most expectations of PBs transformative potential are based.

\section{PBs Transformative Potential}

Based on the vast literature on Porto Alegre we can discern four dimensions of political society on which PB can have a positive effect: on citizen's capacities and attitudes, on civil society organizations (CSOs) on the state and on state-society relations.

Transforming citizens: PB is first and foremost explicitly directed at incorporating poor inhabitants in decision making processes that directly affect their lives. It thereby gives ordinary people the capability of voice, and makes this count in public discussions. Ordinary citizens are motivated to participate in the process, being offered the reward of projects. They have to be knowledgeable about the rules of the game and the basic principles of project budgeting. They have to be capable and willing to negotiate over these budgets among themselves and vis-à-vis the government [18]. PB has the potential to strengthen citizens' agency, especially when agency is taken in Gidden's original sense as "the capacity to process social experience and to devise ways of coping with life... Within the limits of information, uncertainty and the other constraints...that exist, social actors are knowledgeable and capable ${ }^{, 4}$. Citizen's agency is then strengthened when his/her capabilities and knowledge are enhanced. Through public deliberation and the transfer of real decision-making power to ordinary citizens, their capabilities are extended from vote to voice. PB thus offers ordinary citizens the possibility to exercise one of their most fundamental human capabilities: the capability to choose [24]. Although the rules of the PB process are far from easy, participants are capable of learning these rules [7,25]. This learning mainly takes place through prolonged participation. Participants are trained throughout the process, and become more knowledgeable on municipal finance, municipal planning and the general state of affairs in the city. If people participate in consecutive PB-cycles, $\mathrm{PB}$ is also expected to transform them from passive voters into active, responsible citizens. The rationale behind this expectation is that the more often people engage with each other exercising their (newly gained) rights in participatory budgeting, the more likely they are to support and practice democratic rules and values. Following Sen [26] it is expected that the continuous practice of democracy transforms citizens, and can also play a major part in the formation of values. Participatory Budgeting is therefore also labelled "citizenship school" [12]. Through taking part in public discussions, individual participants learn to relate their personal needs to the public interest, in addition, they learn to appreciate the needs of others [27]. The citizenship school is open to all. It should be noted though that especially studies from cities other then Porto Alegre note that $\mathrm{PB}$ tends to attract those that are already politically active, leaders of civil society organisations instead of ordinary citizens [16-18]. It can even function as a strategy for upward social mobility for CSO-leaders [28].

\footnotetext{
${ }^{4}$ Giddens [22] thoughts as summarized in Long [23] emphasis by the author
}

\section{Transforming Civil Society}

Participatory Budgeting is associated with a transformation of civil society in various ways. PB fosters the formation of new CSOs at various levels. Organizations that were dormant are activated, and increase their number and scope of activities. Since successful grassroots mobilization increases the chances of securing investments, PB motivates the establishment of new organizations [29]. In Porto Alegre the number of neighbourhood associations more than doubled in the first decade of PB [25]. The "citizenship school" argument holds even stronger for the CSO-leaders, especially those that participate in the process for a prolonged period of time. CSO-leaders are trained, widen their horizons, form ties with other associations and may improve the functioning of the organizations they represent. PB is associated with the scaling up of CSOactivities (from the neighbourhood to municipal and sometimes even higher levels), and renewing leadership. Also the ties between CSOs are strengthened and intra-group solidarity can be fostered $[10,25]$. Therewith CSO as a collective actor gains strength and can start to act on issues other than $\mathrm{PB}$ as well. For the functioning of $\mathrm{PB}$ it is crucial that the CSO-network is capable of cooperating with government, but also to contend with its policy and pressurise the government if needed [18]. The possible transformation of CSO thus covers the strengthening of the organizations and their leaders, the widening of their scope of action, the scaling up of their activities and the formation of ties and networks.

\section{Transforming the State}

The attitude of the (local) state is crucial in PB. Both elected politicians and the bureaucracy can either foster or undermine its successful implementation. The change of the state therefore can be considered both a conditio sine qua non, and a result of PB. These changes cover three dimensions of the state: the relation between the legislature and the executive, changes within the bureaucracy and changes with respect to transparency and accountability.

Participatory budgeting implies a fundamental change in how preferences are aggregated. Instead of distanced politicians deciding on citizen's needs, ordinary citizens deliberate and prioritize. These citizens are supposed to be better aware of their needs and priorities than distanced politicians. It is thus expected that decisions taken in participatory processes lead to more effective interventions, and a more effective state ${ }^{5}$. A state seen as responsive to such broad based input will furthermore enjoy higher levels of legitimacy [31]. However, when citizens decide over (part of) the investment budget of the municipality, the legislature inevitably looses influence on budgetary decisions. In most PB-set ups the final approval of the budget still rests with the municipal council. Yet, overruling decisions taken in a process of popular participation is unattractive for municipal councillors for electoral reasons. Fierce opposition to the introduction of $\mathrm{PB}$ from the legislature because of the

\footnotetext{
${ }^{5}$ Cameron [30] counters this "effectiveness" argument by demonstrating that in rural municipalities in the Andes PB often results in the prioritization of "cement projects" because these projects are associated with progress. Yet these cement projects do not necessarily serve developmental goals best.
} 
reduction of their influence and power is not uncommon. The availability of pork barrel projects to buttress electoral support is seriously reduced if not annulled. The role of bureaucrats changes in a similar manner: they are expected to put their (professional) skills at the service of citizens' decisions. The projects proposed in the PB process have to be translated into feasible and viable projects and their related budgets. Last but not least, $\mathrm{PB}$ is expected to significantly enhance the state's accountability. PB introduces several mechanisms that allow for additional checks on and monitoring of the state by engaged and interested citizens. Through increased transparency PB is also expected to reduce corruption and clientelism. Increasing accountability is a two-way process. Without government officials genuinely seeking to increase transparency, accountability is impossible to extend. Yet, without citizens actually using the newly created institutional mechanisms, including, if necessary, the extra-institutional mechanisms to pressure government to respect the agreements, accountability is a concept void of meaning [18].

\section{Transforming State-Society Relations}

PB creates new public arenas in which citizen's demands are brought forward and are debated. These new public arena's have been labelled "new public spheres" (echoing Habermas' public sphere) [32]; "PB-deliberative space" [20], and "invited space" [33] cf. [34]. Tarso Genro, Porto Alegre's second PT-mayor labelled it a "non-state sphere of social control or accountability" [10]. Crucial is that a "sphere" or "space" is created between, on the one hand, the traditional sphere of civil society (in all its different forms of civil association), and on the other hand the (local) state. Although the functioning of this sphere is facilitated by the state (hence: an "invited space"), it are the citizens that deliberate. In these deliberations the sum of private needs of individual citizens can become public interests, to be weighed against other public interests. Proponents of "deliberative democracy" even argue that through the creation of these deliberative spaces procedural democracy becomes substantive democracy [29]. It is important to note that in such a "deliberative space" the various localized "public spheres" (either territorial or thematic fora) are not autonomous, but both linked to each other and linked to the state. This is necessary to ensure not only the resources are allocated, but that also cross-border problems (for instance from other neighbourhoods or sectors) are discussed. This is also a necessary condition to create the earlier mentioned group-solidarity, and to foster the diffusion of learning and innovation [35]. Deliberative democracy forms an alternative "state-civil society regime". A "state-civil-society regime" is understood as "a stable pattern of state-civil society interactions, whose defining feature is how societal demands are recognized... (which) establishes a new political logic that becomes an accepted way of resolving conflict between actors in society" (p18-19)[10]. Deliberative democracies - Baiocchi [10] labels it empowered participatory democracies - are characterized by high openness to societal demands, low constraints on civil society and bottom up participation for the aggregation of societal preferences.
When assessing PB's transformative potential it is important to keep in mind that the development of local democratic institutions is never a linear process [29], or, in the words of Holston, that democratization is a disjunctive process [36]. Holston calls democratization disjunctive because new democratic rights or institutions can be developed where simultaneously other institutions can erode. Some institutions may consolidate where others are undermined - democracy is always becoming and unbecoming, both expanding and eroding [36]. Less successful participatory experiments can even leave "footprints" or "residual traces" that can become part of the political memory of citizens, CSO-leaders and politicians. Then they form a newly acquired political repertoire, that can be picked up in future political struggles ${ }^{6}$.

\section{PBS INTRODUCTION: CONTRASTING ORIGINS AND SETTING}

\section{Brazil and Porto Alegre}

When in 1980 the Brazilian military government loosened its tight control and allowed the formation of new political parties, the Partido do Trabalhadores (PT) was formed out of a broad based coalition of radical labour unions, progressive Christian activists, grass-roots urban and rural social movements, and formerly radical Marxist political parties and intellectuals. In contrast to the traditional socialist or communist parties the PT explicitly promoted a bottom - up, participatory organizational structure, and an internally plural ideological structure [6, 10]. The diverse constituencies mentioned could co-exist in the PT, as a party "where social movements can speak" (p.11) [10]. These "social movements" were mainly formed from the mid 1970s onwards. Neighbourhood associations had a pivotal role in organizing these movements [7]. During the first democratic period in Brazil (1946-1964) there were very few urban voluntary associations. The only exception is the city of Porto Alegre, the city with the oldest tradition of neighbourhood associations [37].

In their early years these urban social movements promoted their demands for land, housing and basic services, without questioning the prevailing clientelistic and exclusionary status quo. A status quo of a political culture in which "the neighbourhood, the market, the church and the tavern are public (and) the formal spaces of politics (government and parliament) appear as the private spaces of the educated and the privileged" (p.121) [7]. Throughout the 1980 s, a "crucial change occurred in the urban social movements and organizations, when residents began to understand their social needs as rights of citizenship, and to generate rights-based arguments to justify their demands."(p.240) [38]. This change of both discourse and practice was especially appealing because it offered the hitherto excluded a strategy to counter their exclusion through the demonstration of competence ("know your rights"). Their "Rights to the city" argument embodied the recognition of being citizens who bear the right to have rights $[38]^{7}$.

\footnotetext{
${ }^{6}$ Personal communication from Heller to Wampler [18].

${ }^{7}$ See for an overview of the influence of the diverse social movements on the new conceptualization of citizenship in Brazil [39]. Holston [38]
} 
In 1982, the National Movement for Urban Reform (MNRU) was founded, bringing together an amalgamation similar to that of popular movements that had formed the PT. Yet not only neighbourhood organizations, trade unions and other base-organizations joined forces, also NGOs and professional organizations formed part of the movement. Its aim was to elaborate a proposal on urban reform during the National Constitutional Assembly, which had been created to draft a new constitution. The Constituent Assembly led to an unprecedented level of popular participation, thanks to the provision that it accepted popular amendment proposals. An estimated 12 million people subscribed popular amendments. The popular amendment of the MNRU was in a slightly diluted form included in the new constitution in 1988, also known as "The People's Constitution" [37]. It required another almost 13 years to translate the principles from the constitution into a piece of intra-constitutional legislation, a project that became known as "Statute of the City", approved in 2001.

This Constitution of 1988 decentralized both responsibilities and funds to the municipal level, thereby breaking with the dictatorship's centralization [10]. Brazilian municipalities are now responsible for $15-18 \%$ of all public spending, this is 7\% of Brazil's GDP [18]. Baierle [9] calls this development a "perverse" decentralization. With this share in the budget, municipal governments do not only have to provide for the classic services such as urban infrastructure, safety, social assistance and local economic development, but also for day-care centres, primary education and health. The decentralization of responsibilities and funds was not complemented by a revision of the relations between the executive and the legislative branch of government, leaving full discretionary authority over the investment budget in the mayor's hands [18].

The PT gradually gained electoral success. They won two municipalities in the 1985 local elections; in 1986 they won some seats in congress and in the 1988 local elections they won 36 municipal governments, including three state capitals: the megalopolis São Paulo, Victoria and Porto Alegre. The PT's victory was made complete by the PT's Luis Ignació Silva winning the national presidential elections. Lula was re-elected in 2006 [6, 37].

Inherent to its beginnings as broad based social movement, there was no such thing as a "PT-way of governing", and virtually all PT municipal governments had to come to terms with factional disputes over the meaning of a PT-administration. ${ }^{8}$ Porto Alegre's experiment in Participatory Budgeting became a source of inspiration. In the 1990s the practice spread to over 200 Brazilian cities, home to $43 \%$ of the Brazilian population [9].

In Brazil, and especially in Porto Alegre, PB can be considered to be the institutional expression of this decades long effort to extend rights, whereby citizens increased their control over their lives by increasing their authority over

convincingly presents how specifically the urban nature of the struggle for land, housing and basic services created this new form of citizenship. Baierle [7] tells a similar story about the formation of a new ethical political culture in Porto Alegre.

${ }^{8}$ See for accounts of both successful and unsuccessful PT-administrations Baiocchi [15] and Wampler [18]. their government [18]. In Porto Alegre PB was the result of a synergetic state-civil society encounter in which new rules of the game of interaction were drafted. The newly elected PT government had to find a way to fulfil its two main election promises that it would "revert spending priorities," to address poverty and inequality, and that it would increase popular participation in local decision making. Both at the national as well as at the local level it was the PT's explicit aim to democratize both society and the state $[6,7,10]$. PB was designed to be instrumental in this process through four key-characteristics:

- Direct citizen's participation in government decision making;

- Transforming residents into citizens, aware of their democratic rights;

- $\quad$ Fiscal and administrative transparency to prevent corruption and clientelism;

- Concrete improvements in infrastructure and services, with an emphasis on redistribution [4].

When the PT assumed office in Porto Alegre, it inherited an almost bankrupt municipality, a bureaucracy in disarray where financial information and administrative records were lacking and taxes had not been updated in line with the hyperinflation of that era [20]. The first mayor Olivio Dutra ${ }^{9}$ staffed his administration with PT-activists without municipal experience. They considered that they had no other opportunity than a bold move forward; they organised a series of open assemblies to inform the citizenry of the dearth state of affairs of the city. It was civil society especially the union of neighbourhood associations - that consistently demanded popular decision making power in budgetary matters. In August 1989, a first round of five participatory meetings on the budget took place. In dialogue between civil society and the state a set of PB-rules were crafted over the years, and institutionalized. Important civil society demands honoured in the PB-design were that popular participation in decision making was not limited to one assembly, but spread over a series of meetings that provided for proper preparation, deliberation and monitoring. It also provided for a form in which citizens not only could discuss investments at neighbourhood level, but also debate city-wide policies. PB has been a learning experience for both citizens and governors [10]. The fine-tuning of the PBrules continued until 2005 [40].

Although the fiscal and political conditions were unfavourable in 1989, several conditions in Porto Alegre were conducive to the successful development of PB. Porto Alegre is the relatively affluent capital of Brazil's wealthiest state, Rio Grande do Sul. The average income, education level and life-expectancy were already well above the national average [20]. Porto Alegre furthermore had a vibrant civil society. Since the 1950s, neighbourhood movements had been formed, which in the seventies and eighties went through a vigorous experience of popular

\footnotetext{
${ }^{9}$ Olivio Dutra was one of the founding members of the PT. As mayor of Porto Alegre (1989-1993) he headed the first years of the PB-experiment. In 1999 he was elected governor of the State Rio Grande do Sul and implemented PB at state-level. In 2003 he became the first "Minister of Cities".
} 
education based on the philosophy of Paolo Freire. Popular Councils were formed in which people experimented with embryonic forms of popular participation and debate [8]. In Porto Alegre PB could thus build on the footprints of earlier participatory experiments. And on the political side of the equation there also existed a stronger political culture in Rio Grande do Sul than in other Brazilian states, and a more auto critical and reflexive culture within the PT [41].

\section{PBs History in Peru}

Inspired by visits from protagonists from Porto Alegre, two Peruvian local governments started PB experiments in 2000, namely in Villa El Salvador and Ilo. Both municipalities were governed by mayors from the progressive Izquierda Unida (United Left) and both municipalities were known for their tradition of popular participation in local decision making [28, 42-44]. In the same year, President Alberto Fujimori was forced to step down. This brought an end to 10 years of what Peruvians called a "demodictadura": authoritarian rule under a democratic veil, behind which corruption was rampant and the president had developed a highly personalized style of "neo-populism" [45]. The country had undergone a profound process of re-centralization in which by the end most power and resources were concentrated in the hands of the "Ministry of the Presidency". The country's democratically elected regional governments had been abolished and had been replaced by appointed regional authorities, and municipal competencies and budgets had been curtailed. In 2000, Peruvian municipalities spent $4 \%$ of the national budget, this being one of the lowest shares on the continent [28]. In several localities - for instance in the cities of Ilo and Villa El Salvador - civil society had survived the decade of Fujimori. However, in general one can argue that civil society had seriously suffered from authoritarian rule. "CSOs were pervaded by corruption, individualism and egotism" (p.107) [46]. In the vast peripheral districts of Lima and several Andean provinces they had furthermore suffered from the years of violence, in which the terrorist movement the Shining Path had specifically targeted community leaders [28].

After the return to democracy, the country embarked on an ambitious reform program. Major goals were to recreate democratic institutions through increased citizen participation, to improve transparency and access to public information, and to pursue poverty eradication and stability of the economy. The government created consultative spaces where civil society had an important role in framing major policies. Most successful of these spaces for "social dialogue" are the "Mesas de Concertación ${ }^{10}$ para la Lucha contra la Pobreza" (MCLCP), or Round Tables in the Fight against Poverty, functioning at national, regional and local level $^{11}$.

\footnotetext{
${ }^{10}$ I have argued elsewhere that concertación can not be adequately translated. It goes beyond consultation and brings the different stakeholders around the table so that solutions can be negotiated and responsibilities assigned. This includes conflicting interests, where these exist (p.71) [47].

${ }^{11}$ According to their own inventory of the 1454 existing round tables, over $30 \%$ are currently active, 26 at regional level $(100 \%), 153$ at provincial level $(78 \%), 533$ at local level (29\%). See www.mesadeconcertacion.org.pe, retrieved March 12009
}

A wide range of political actors, private sector institutions, professional guilds and civil society representatives signed the Acuerdo Nacional (National Agreement), articulating thirty state policies to be achieved over the next 20 years. Most reforms were only implemented haltingly or not at all. There is general agreement that the government of Alejandro Toledo only made headway on one aspect of his reform agenda: political decentralization [48, 49]. Transfers from national to regional and local governments increased substantially in this period. The share of local governments in the state budget increased from $4 \%$ in 2000 to $12 \%$ in 2008 , the share of regional governments from $15 \%$ to $17 \%$ between 2004 and 2006 [28, 50]. Since the overall state budget increased from 44 billion to 71 billion Peruvian Soles between 2004 and 2008, the budget increase at local level in absolute terms was even more substantial. Municipalities experienced a multiplication of their budgets within a few years ${ }^{12}$. It should be noted though that for many municipalities this meant an increase from "almost nothing" to "a little more". More than three-quarter of the Peruvian municipalities had an investment budget of less than US\$ 315.000 in 2005 [51].

In 2002, the Peruvians could democratically elect regional governments. In the same year, the Peruvian Government issued two important laws on decentralization, namely the Law on Decentralization, and the Law on Regional Governments. The new legal frameworks also provided the right to access to public information, and transparency. All government levels are, for instance, required to publish information on their budgets, acquisition, tenders and remunerations, and to update this information on a monthly basis. In the Law on Decentralisation, the principle of participatory budgeting was included. Article 20 of the Law on Decentralization reads:

\section{The regional and municipal governments sustain themselves and govern through yearly participatory budgets as instruments for their administration, these participatory budgets have to be formulated and executed in conformity with the law and in correspondence with the Concerted Development Plans (author's translation).}

The introduction of Participatory Budgeting through national government legislation was part and parcel of Toledo's ambitious decentralization package. The government was, however, by no means united on its introduction. These divisions run through the executive and the legislative branch of government, among politicians and in the bureaucracy. In the legislature there was a clear division between reformist and conservative congressmembers. Although one could roughly say that PB's promoters were to be found among Left-wing politicians the former IU mayor of Ilo being one of the catalysts behind the law - and its opponents from the right, this division was by no means clear-cut. Opponents argued that PB would undermine the institutions of representative democracy. Within the state bureaucracy there were protagonists and

\footnotetext{
${ }^{12}$ Much of the increase of the Peruvian budget in these years was the result of the high prices of minerals in recent years. Seen the recent fall of these prices at the world market, the budget will decrease probably substantially.
} 
antagonists, with the Directorate General for the Budget of the Ministry of Economy, (Dirección Nacional del Presupuesto Publico, DNPP-MEF) as unexpected and unusual promoter of PB. DNPP-MEF even started pilot projects in Participatory Budgeting at the regional level in 2002, even before the relevant laws were adopted. To complicate matters even more, legislation regulating $\mathrm{PB}$ came from different sources. The laws on Regionalization and Decentralization were prepared in the relatively progressive National Commission on Decentralization (CND), discussed in the Congressional Committee on Decentralization and enjoyed broad based electoral support. The "Framework Law on Participatory Budgeting" was prepared with technical support from the DNPP-MEF. However, discussions in the more conservative Congressional Economic Committee were far more contentious. The two commissions never coordinated, and the Decentralization Committee had not even seen the Framework law on Participatory Budgeting before it was presented in Congress [46, 48, 52]. The PB-law almost did not pass, and what was finally adopted in 2003 was a product of many political compromises. To win support of those legislators wary of direct democracy, several mechanisms were introduced that reduced the direct voice of citizens [52]. The objective of this new legislation was to design "[a] mechanism to assign public resources in a just, rational, efficient, effective and transparent manner, which strengthens the relationship between the state and civil society" (Ley Marco, article 1, author's translation). The final regulations on PBs implementation still were to be developed in separate "Participatory Budgeting Guidelines". DNPP-MEF created and sponsored an ad-hoc working group, which was later on institutionalized as the "Colectivo Interinstitucional del Presupuesto Participativo" (henceforth Colectivo Interinstitucional), with an interesting composition. It is composed of the earlier mentioned Round Table against Poverty, some NGOs and their umbrella organizations ANC and Red Peru. As local government actor, the Association of Rural Municipalities (REMURPE) participates. International donors sponsored two important projects to support the decentralization process, Participa Peru and PRODES. These projects participate in the Colectivo Interinstitucional, as well as the international donors US-AID, Care, UNIFEM and UNICEF. Nowadays also national state entities other than DNPP-MEF with a stake in PB participate: the Secretariat of Decentralization (successor of the earlier mentioned Commission on Decentralization), the Ministry of Women and Social Development, and the Social Development Fund (FONCODES). The Colectivo Interinstitucional became an important deliberative space in which the progress, bottlenecks and suggestions for improvement of the PBprocess were discussed. These deliberations led to a number of changes in the PB-rules and regulations as published annually by DNPP-MEF. At first sight these PB-rules seem very similar to the PB-rules developed in Porto Alegre. A closer look however, reveals that the PB-rules in Peru differ in three crucial aspects from the Porto Alegre template that became the international point of reference.

\section{CONTRASTING PORTO ALEGRE'S AND PERUVIAN PB-RULES}

\section{Porto Alegre}

The PB-rules of Porto Alegre's PB are the result of ongoing deliberations between government and civil society, and have been adapted each year. We can roughly distinguish three phases ${ }^{13}$.

Phase 1: Public deliberation and direct democracy: (March/ May). The process commences with numerous informal meetings in the neighbourhoods, in the 16 regions of Porto Alegre, in which the results of last year's PB are presented and discussed. The available budget for the coming year is also announced. In March, the municipality organizes 22 formal fora, one for each of the 16 regions of the city and one for each of the six sectoral themes that are considered of citywide importance: (1) transit and public transport; (2) culture; (3) economic development; (4) education and leisure; (5) urban and social development; (6) health and social welfare. In these fora, open to all citizens who wish to participate, three important decisions are taken. Firstly, each region/theme-forum decides on the spending priorities for the coming year. This selection of priorities is based on the principle of "one-man-one-vote". Secondly, the number of delegates the forum can deputise is determined, according to the formula "one delegate per 10 participants in the forum", ${ }^{14}$ and these delegates are elected. Lastly, from this group of delegates the "PB-councillors" that represent this forum in the PB Council are elected. The PB council is the principal body of the PB process. It consists of regional and thematic councillors (two per forum), plus a representative from the municipal union and a representative from the Union of Neighbourhood Associations. Two municipal employees are added, but only in an advisory capacity. The PB-council oversees and organizes the entire PB-process, controls the implementation and deliberates on the internal rules. With this election of the PB-councillors the phase in which all inhabitants of Porto Alegre had a vote in this exercise of direct democracy is concluded.

\section{Phase 2: From Priority to Proposal (May-July)}

In a new series of informal meetings in the neighbourhoods, the newly elected delegates discuss with the population how to translate the chosen priorities in concrete

\footnotetext{
${ }^{13}$ This presentation of the PB- rules is based on Chavez [20], and includes all changes incorporated until 2002. This includes the important change to reduce a long and relatively complicated process of two rounds of regional and thematic assemblies with a round of informal neighbourhood meetings in between to one a short period of ca. 6 weeks of public deliberations. These changes were proposed by involved grassroots organizations, as well as municipal staff and researchers (p.167) [20]. It is this set of PB-rules that became an international reference point. It does not include changes that have occurred since the PT lost the elections in 2004 to the Brazilian Democratic Movement Party (PMDB). Both Baierle [9] and Chavez [40] report that PB has been hollowed out: PB has been made "one consultative space among many others" [9] and the number of public works executed has dropped dramatically [40]. The PMDB mayor defeated the PT candidate in most recent local elections (2008), and has recently started his second term in office.

14 To avoid that large neighbourhoods would have a disproportionate advantage over smaller neighbourhoods a sliding scale was developed: for 10-100 participants, 1 delegate per 10 participants; for 101-250 one additional delegate per 20 participants, for $250-400$ delegates an additional delegate per 30 participants etc [18].
} 
investment proposals for next year's budget. Once all proposals are received, the delegates make a city-tour to visit all sites for which concrete projects have been proposed. In a second series of fora, this time only open to the delegates, the deliberation takes place on the prioritization of the proposed projects. This is concluded with a comprehensive "Municipal Assembly", in which the delegates officially present the prioritized projects to the municipality. In the same meeting, the newly elected PB-councillors are installed. This municipal assembly is open to all citizens, but no voting on projects takes place.

\section{Phase 3: Technical Elaboration (July-December)}

In this last phase, the newly installed PB-council works in close coordination with all relevant municipal staff on the translation of the proposed projects into a fully-fledged technically viable and financially feasible investment plan. A first version of the budget is discussed with the delegates in their respective fora, and thereafter presented to the municipal council. The municipal council approves or rejects the budget.

As stated earlier, PB provides a "public non state sphere of deliberation", an interface between state and civil society. The adequate functioning of this sphere required changes in the local state apparatus. The municipality created a specific office, the planning cabinet. Its main task is to coordinate all technical work behind the PB-process, such as the translation of the PB proposals into the language and format of municipal financial planning. They also appointed regional and thematic PB coordinators, and established eight decentralized municipal offices to provide basic administrative support to the $\mathrm{PB}$ and the everyday relationship with the population.

\section{Peru's PB-Rules and Regulations}

As stated earlier, in Peru the PB-rules are issued yearly as "Participatory Budgeting Guidelines", and changes in these rules were mainly the result of deliberations in the Colectivo Interinstitucional. The overall format has however remained the same over the years. The process commences with the providing of information, to be followed by training the participants, deliberations in a series of workshops, the adoption of agreements, and, finally, the oversight and monitoring of the execution of the agreements ${ }^{15}$.

However: in contrast to the Porto Alegre model of a Participatory Budgeting Council which consists of civil society members as the highest organ in the PB-process, the Peruvian law stipulates the formation of so called Regional and Local Coordinating Councils (CCR and CCL respectively). These CCR/CCLs should be composed of $60 \%$ state-representatives and $40 \%$ CSO-members. It is

\footnotetext{
${ }^{15}$ In the Guidelines 8 steps are specified: After initial preparations (1) the municipality publishes a call for participation (2), the people and CSOs interested to participate have to register as "participating agents", these participating agents have to be trained (4), and then enter a series of workshops (5). Also the sequence of the workshops is indicated: to develop an update of the development plan, define the criteria to prioritize projects, define problems and priorities, define projects to be prioritized. In the next phase the technical team has to assess viability of the proposed projects and their budget (6). Thereafter agreements reached in the CCR/CCL have to be formalized and to be presented to the municipal council (7). The last step is monitoring and account for implementation of the decisions.
}

furthermore legally laid down that at least $30 \%$ of the civil society representatives should be coming from entrepreneurial organizations. Local and regional governments are encouraged to include a further specification of the PB-rules in their by-laws, for instance to ensure proper gender divisions, the inclusion of indigenous groups where relevant and/or the inclusion of other marginalized groups [48]. The strong state representation in these Coordination Councils is one of the compromises with those who feared the undermining of representative democracy. The result however, is that ambiguity is increased, since the competencies of the Coordination Councils vis-à-vis the normal Regional or Municipal Councils are not clearly defined. The task of monitoring of the implementation of agreements reached is assigned to a specific organ, the so called oversight committee (comites de vigilancia). Yet, there are no sanctions on the noncompliance with any provision of the law, with the result that these oversight committees have little tools to sanction transgressors. It is important to note the sharp difference with the Participatory Budgeting Council in Porto Alegre, which is explicitly a civil society space where government official only have an advisory role. In Peru, the deliberations on PB thus do not take place among citizens, but between citizens' representatives and government representatives. The latter always possess the majority vote in the coordinating council (CCR/CCL).

Moreover, in Porto Alegre every citizen can participate, and these citizens elect their delegates. Everybody can become a delegate. In Peru, there are two mechanisms limiting the participation of ordinary citizens. To participate in the series of workshops most similar to the phase of direct democracy in Porto Alegre, citizens first have to register at the municipality as "Agentes Participantes". The invention of "participating agents" was developed in the more conservative Economic Committee in Congress, with the apparent intention of diminishing the role of the CCR/CCL [46]. Originally there was a complex criterion one had to fulfil in order to be able to register, namely being a representative of a legally registered CSO with at least three years of existence. In later years this requirement was loosened, since it excluded many community organizations. It furthermore did not make much sense, since also "representatives of the unorganized parts of society" could participate - leaving unexplained how unorganized parts of society do choose their representatives. To complicate matters even more the yearly guidelines even allowed for "natural persons" to register [53]. This resulted in a mix of "agentes participantes" representing organizations - either on paper or in practice - and individuals. Several studies question to what extent these "participating agents" actually represent the organisation they claim to represent, and actually deliberate with their constituents [33, 48, 54-56].

Civil society members of the CCR/CCL have to represent a CSO. To be able to become part of the CCR/CCL CSOs even had to have legal registration (persona juridica), which posed a very serious barrier for many CSOs who lack this registration [46]. Even more problematic is that the tasks and responsibilities of the workshops with the "participating agents" and the CCL/CCR are not clearly defined. They function as parallel institutions with partly overlapping functions, which adds up to the already noted ambiguities in 
tasks and competencies of CCL/CCR versus the municipal council.

The third important difference between the procedure in Porto Alegre and in Peru is the role assigned to the civil servants. In Peru, each locality has to form a technical team, that translates the proposed projects in feasible proposals that also have to meet the stringent technical specifications of the national accounting system. The technical team must approve the budget of project proposed. However, it can make modifications to it, or even entirely reject projects based on viability standards of the DNPP-MEF and the national accounting system (SNIP). Civil servants thus have the power to overrule decisions resulting from the PBprocess. A clear example of the influence of the Colectivo Institucional concerns the guidelines of 2006; it includes the provision that the technical team should incorporate representatives from civil society. The representatives can be either professionals or CSO-representatives and members from the Roundtables against Poverty. It does however depend on the capacities of these civil society members whether they can counterbalance the bureaucrats' influence.

In 2006, Alan García - the candidate of the party that most vehemently opposed participatory budgeting - won the presidential elections. Although he indicated that he did not favour Participatory Budgeting, so far he has taken no measures to revert the process. The implementation of PB in Peru is gradually increasing and improving.

\section{The Implementation of PB in Peru and its Transformative Potential}

Since 2005 the Ministry of Economy and Finance (MEF) tries to monitor the implementation of the Participatory Budgeting in Peru through an interactive website ${ }^{16}$. Also the Round Tables against Poverty and the Colectivo Interinstitucional monitor PB's implementation and have published evaluations $[54,57,58]$. Since the promulgation of the Law in 2003 the number of registered PB-processes increased from 537 in 2004 to 661 by September $2007^{17}$, covering roughly a third of Peru's sub-national governments. Since all major cities implement PB - at least in name - it covers the localities where more than half of the Peruvian population lives. Although these numbers should be taken with some caution - not all municipalities running PBs will register, and some that register might only run $\mathrm{PB}$ in name Table 1 also shows that around 40.000 "participating agents" took part in the registered processes. Since we assume an underreporting by the municipalities the actual number will be even higher. The evaluation of the Round Table against Poverty ${ }^{18}$ reported a $22 \%$ increase in the number of people participating in PB-workshops between 2005 and 2006 [57].

\footnotetext{
${ }^{16}$ Unfortunately it seems that subnational governments have decreasingly taken the effort to provide DNPP-MEF the necessary information. In September 2008 DNPP-MEF even published an official statement in the law-gazette El Peruano naming all Governments that had not yet registered the results of that years PB process, being more than $60 \%$ of the subnational governments [59].

${ }^{17}$ Since 2008 it is no longer possible to run a query online at the DNPPMEF website. It was therefore impossible to complete the data for entire 2007 , and data on 2008 are lacking.

${ }^{18}$ MCLCP (2007) surveyed 174 cases of PB: 20 at regional level, 60 at provincial level and 94 at district level, therewith thus covering between $20 \%-25 \%$ of the registered PBs. They furthermore surveyed 1291
}

More important than its spread in quantitative terms is the quality of the process. As mentioned earlier PB can also be run just in name, and then it will have little transformative potential.

Table 1. Number of Registered PBs and Number of Participating Agents by Government Level

\begin{tabular}{|c|c|c|c|c|}
\hline & 2004 & 2005 & 2006 & 2007 \\
\hline \multicolumn{5}{|l|}{ Number of PBs Registered } \\
\hline Regional Government & 24 & 25 & 25 & 25 \\
\hline Provincial municipalities & n.a. & 111 & 85 & 104 \\
\hline District municipalities* & 513 & 664 & 376 & 532 \\
\hline Total & 537 & 800 & 486 & 661 \\
\hline \multicolumn{5}{|c|}{ Number of "Participating Agents" } \\
\hline Regional Government & & 2392 & 3896 & 1918 \\
\hline Provincial municipalities & & 6997 & 10667 & 8369 \\
\hline District municipalities & & 20672 & 29324 & 26781 \\
\hline Total & & 30061 & 43687 & 37068 \\
\hline
\end{tabular}

\section{Transforming Citizens}

In the Peruvian process there are a number of instances and roles in which civil society can participate: as "participating agent" in the first series of workshops, as member of the CCR/CCL, as member of the technical team, or as member of the oversight committee. Theoretically, it is only in the first series of general workshops that an ordinary citizen can participate, provided that he/she has registered previously at the municipality. However, even in these workshops $45 \%$ of the participants are public sector representatives. Furthermore, at district and municipal level on average only $15 \%$ of these CSO-participating agents has been capable of presenting projects that met the technical standards of the national accounting system SNIP. The difference with the processes in the 26 regions is significant: here $43 \%$ of the participating agents from civil society presented projects that met the standards [54]. This is not surprising if we look at what kind of organizations the civil society participants come from.

From Table 2 we can first of all draw the conclusion that almost all participants consider themselves representing an organization. We have already mentioned that one originally even had to prove that one was representing an organization in order to be able to register as "participating agent". Although this is no longer a prerequisite, it are still by far and most the CSO-leaders and active CSO-members that participate in PB. We can furthermore note that women's participation at regional level is substantially less than at district level. There are fewer female participants at this level, and only $3 \%$ of the participants represent a women's organization. Ordinary citizens are often either unaware or

participating agents, 201 from regional PB-processes, 431 from provincial and 659 from municipal level. 
Table 2. Kind of Civil Society Organization by Government Level (2006)

\begin{tabular}{|c|c|c|c|c|}
\hline & District Level & Provincial Level & Regional Level & Total \\
\hline Neighbourhood association & $42 \%$ & $33 \%$ & $29 \%$ & $37 \%$ \\
\hline Peasant/indigenous organization & $10 \%$ & $14 \%$ & $5 \%$ & $10 \%$ \\
\hline Women's organization & $19 \%$ & $15 \%$ & $3 \%$ & $15 \%$ \\
\hline Educational sector & $11 \%$ & $12 \%$ & $23 \%$ & $14 \%$ \\
\hline NGOs - International donors & $1 \%$ & $2 \%$ & $10 \%$ & $3 \%$ \\
\hline Private sector & $9 \%$ & $9 \%$ & $13 \%$ & $10 \%$ \\
\hline Political parties & $0 \%$ & $0 \%$ & $1 \%$ & $0 \%$ \\
\hline Other & $8 \%$ & $15 \%$ & $16 \%$ & $1 \%$ \\
\hline Total & $100 \%$ & $100 \%$ & $100 \%$ & $100 \%$ \\
\hline \multicolumn{5}{|l|}{ Gender Representation } \\
\hline Female participants & $36 \%$ & $29 \%$ & $27 \% \%$ & $29 \%$ \\
\hline
\end{tabular}

Source p. 40, Table 36 [57].

uninterested in what is going on. They lack the necessary information and capacities to participate in the process [28, $48,51,56]$. A lack of funds to publicize the efforts is considered one of the causes [54]. Yet, general disinterest might also be a reason. Furthermore, in the legal framework there are no mechanisms foreseen in which the civil society representatives interact with their constituents. In several localities this has been remedied by introducing "general assemblies", open to all citizens to inform them. But Grompone [48] unreservedly characterizes PB as a process in which only a small proportion of the population is interested. On the one hand, he remarks, that if it does not reach a wider public and participation in the near future, it will simply reproduce existing power configurations. On the other hand we should be realistic - according to Grompone in the sense that the poorest of the poor will not participate in these kind of processes anyhow [48].

Overall we can conclude that it is the "CSO-elite", already active, that participates in the process. It is however important to note that of those participating, the vast majority is relatively positive about the PB-process of 2006. Especially when contrasted with the overall judgement of Peruvians on the quality of their democracy, it is remarkable that less than $10 \%$ considers the PB-process of bad quality; over $40 \%$ even considers it of good to excellent quality. Researchers are less positive, some even conclude that only $10 \%$ of the PB-cases can be considered to be genuine participatory exercises [60].

Table 3. Quality of the PB-Process 2006 by Governmental Level

\begin{tabular}{|c|c|c|c|c|}
\hline \multirow{2}{*}{ Qualification } & \multicolumn{3}{|c|}{ Level of PB-Process } & \multirow{2}{*}{ Average } \\
\cline { 2 - 4 } & District & Provincial & Regional & \\
\hline \hline Bad & 7,6 & 9,1 & 13,6 & 9,0 \\
\hline Average & 46,0 & 54,5 & 56,8 & 50,5 \\
\hline Good & 38,2 & 33,3 & 28,6 & 35,1 \\
\hline Excellent & 8,2 & 3,0 & 1,0 & 5,4 \\
\hline Total & 100 & 100 & 100 & 100 \\
\hline Source: [57].
\end{tabular}

Implementing $\mathrm{PB}$ is a process of trial and error. It is thus a promising finding that the participants consider the PBprocess of 2006 of a higher quality than the process in 2005 . The study also concludes that the longer one participates in the process, the more positive one becomes [57].

Table 4. Quality of the PB-Process 2006 Compared with 2005 by Governmental Level

\begin{tabular}{|c|c|c|c|c|}
\hline \multirow{2}{*}{ Qualification } & \multicolumn{3}{|c|}{ Level of PB-Process } & \multirow{2}{*}{ Average } \\
\cline { 2 - 5 } & District & Provincial & Regional & \\
\hline \hline Much better & 17,0 & 15,0 & 11,7 & 15,5 \\
\hline Better & 51,0 & 54,8 & 61,4 & 53,9 \\
\hline The same & 23,2 & 23,1 & 19,8 & 22,6 \\
\hline Worse & 6,2 & 5,2 & 6,1 & 5,9 \\
\hline Much worse & 0,6 & 0,7 & 0 & 0,6 \\
\hline Don't know & 2.0 & 1,2 & 1,0 & 1,6 \\
\hline Total & 100 & 100 & 100 & 100 \\
\hline
\end{tabular}

Source: [57].

Tables 1-4 together also reveal important differences between the $\mathrm{PB}$ processes at the different levels of government. It is apparent that at district level the participation of neighbourhood associations and women's organizations is higher than at provincial and particularly at regional level. At regional level, the participation of NGOs and international donors as participating agents is substantial $^{19}$, and also the representation of the educational sector is strong at this level. Although no records are kept of the educational level of the CSO participants, we can safely assume that participants at the regional level have received higher education levels than participants at the district level. This correlates with the finding that especially at the regional level civil society was able to present projects that met the

\footnotetext{
${ }^{19}$ We earlier mentioned the involvement of NGOs and donors in other roles, namely as part of the Colectivo Interinstitucional and in buttressing advocacy and training of CSO-leaders.
} 
quality standards of the national accounting system. Yet, although quality of CSO-projects was the highest at this level, satisfaction with the PB-process was lowest. These data confirm findings from other studies: at the regional level the processes are more formalized, reach higher standards in technical terms and attract better equipped representatives. They are however also less rich in terms of participatory dynamics, and even more distanced from ordinary citizens [48].

\section{Transforming CSOs}

PB was introduced in Peru at a moment that civil society organizations were weak [46], but increasingly responded to the opportunities offered, for instance through the formation of the Round Tables against Poverty and PB. In the first year of $\mathrm{PB}$ civil society participation in the process was very low [46], and of little quality [54]. Both national and international NGOs played an important role in supporting $\mathrm{PB}$, especially through advocacy activities to disseminate the contents of the law - with as clear examples the earlier mentioned projects Propuesta Ciudadana and PRODES and through sponsoring of a wide range of training activities to increase the capacities of CSO leaders. CSO and their allies in fact have been far more active in advocating the new rights than the state government has been. They furthermore developed an educational strategy which combined formal training in workshops with learning by doing throughout the process [46]. Women's organizations were for instance supported in the process of acquiring legal registration (persona juridica), but simultaneously underwent a change of leadership, restoration of internal democracy and organizational strengthening [46]. The capacities of CSO at local level are gradually improving. As the Colectivo Interinstitucional carefully formulates: "The number of trainings provided by public and private institutions is increasing, but still limited. It is below what participating agents need and expect. The level of capabilities of the participants is basic, but we appreciate the improvement in the capacity of organisations to include certain crucial aspects of development in their proposals." (p.9-10) [54], translation by the author). In several localities a number of valuable participatory experiences have been gained, but they remain isolated and incomplete [46]. It is interesting to note that a number of localities where these experiences take place have passed through earlier experiments with participatory governance. This does not only hold for Ilo and Villa El Salvador, but also for instance for San Martin and Huancavelica.

Yet the impact of the introduction of PB on civil society is most notable at the national level. The formation and functioning of the Colectivo Interinstitucional simultaneously mirrors the willingness of (a part of) the state to interact with civil society as well as increasing capacity of civil society to fulfil this role. Through lobbying, through constructing alliances with willing mayors and regional presidents and through the introduction of high quality proposals CSO has managed to have an impact on the PB-rules and regulations. A clear example has been the incorporation of CSOrepresentatives in the technical committees. A second example is the fact that regions and municipalities have broadened the financial base of PB. Originally, only national government transfers from the Social Investment Fund
FONCODES were brought under PB. Nowadays it is also possible to bring tax-income from canon and sobrecanon ${ }^{20}$ under PB, which substantially increases the budget in those regions and municipalities that receive these Royalties, for instance in Ilo. The Colectivo Interinstitucional reported a clear increase in the number of municipalities bringing these resources under PB [54]. Where this happens this can be taken as a clear sign of political commitment to the process.

Through the activities of the Round Tables against Poverty, Propuesta Ciudadana and PRODES civil society organizations have created a vibrant network, which has become an important discussion partner.

\section{Transforming the State}

We already indicated that the change within the state is as well a necessary condition for a genuine PB-process as well as possible outcome. The introduction of PB implies a reduction of the influence of the legislature in budgetary decisions. In theory the legal-institutional situation has thus changed. The safe-guarding of small scale projects which improve the neighbourhood, is a crucial issue for councillors who wish to enhance their constituency. It is thus no wonder that in many localities they resist the changes PB implies. Since the legal framework is unclear and ambiguous in defining the competencies of the $\mathrm{CCL} / \mathrm{CCR}$ vis-à-vis the municipal councils, there is ample space to by-pass the PBagreements. Mayors as well oppose PB. Several studies indicate this lack of political will. It is reflected in the two main weaknesses in Peru's PB-process: a lack of respect for the agreements reached and a lack of implementation of the projects prioritised $[48,58,61,62]$. Last but not least the process requires substantial changes within the bureaucracy, both in terms of procedures as in terms of attitude. Officials in departments of urban development can be unwilling to develop projects proposed by citizens, either because they consider their own proposals of higher quality or because they fear to loose their lucrative income from bribes $[28,55]$. As members of the technical teams they can effectively block project proposals [46]. Especially in smaller municipalities it can also be a lack of manpower. As the Association of Peruvian Municipalities (AMPE) notes: small rural municipalities have less than 10 workers, none of them professional, and DNPP-MEF lacks the capacity to adequately support them.

The new legal framework also introduced a number of mechanisms to increase access to information and transparency. At national level the Ministry of Finance publishes the distribution of funds transferred to regional and municipal governments. The Peruvian Ombudsman - an important CSO-ally - continuously monitors the implementation of the law on transparency and information. In their most recent report the Ombudsman concludes that over $90 \%$ of the regional governments have web-portals in place providing information on the budgets, acquisitions,

\footnotetext{
${ }^{20}$ The canon and sobrecanon are taxes collected from companies exploiting natural resources (mining, fishing, timber and others). Subnational governments receive a share from the taxes collected by the state. Port-cities generate additional local revenues levying port-activities. The distribution of this resource is highly unequal, 4 of the 25 regions receive more than $70 \%$ of the mining royalties. The coastal municipality Ilo has a relatively substantial budget since it combines mining, fishery and port-activities.
} 
tenders and remunerations. On average the regional governments manage to comply with $67 \%$ of the legal requirements, provincial governments with $40 \%$. They also report a substantial improvement reached throughout 2008, though without meeting the requirement of monthly updating this information [63]. Although the Ombudsman demands specific attention for improving the flow of information on participatory budgeting, accountability of $\mathrm{PB}$ projects and the CCL/CCR [63], many governments do publish this information, and at least $30 \%$ also registers this information at the portal of DNPP-MEF. There is nowadays far more information on local government affairs and finances available than in the past, or in the words of the Interinstitutional committee "the level of information is insufficient, but increasing" (p.9) [54].

\section{Transforming State-Civil Society Interface}

We mentioned earlier that less than $10 \%$ of the civil society participants in the process were dissatisfied with the quality of the PB-process in 2006. This is an astute difference when compared with the general opinion about government institutions. In the same year Peruvians graded their democracy with a 5.2 (at a scale 1-10); only Guatemala, El Salvador and Paraguay scored less. Only 20\% considered that through democracy the country is governed in the common interest [64]. All PB-evaluation studies conclude that the relation between civil society and their governments has improved. Or, in the words of the Colectivo Interinstitucional: "Participatory Budgeting is contributing to transform the relations between the state and civil society, through a new form of exercising citizenships, in the framework of implementing mechanisms of participatory democracy.. This participation has a positive influence on the quality of the democracy and the governability, and fosters the intervention of citizens in decision making.... The participatory budgeting processes are also contributing to the transparency in public management, and therewith strengthen relations of trust" (p.6) [54] (translation by the author). Although the functioning of the oversight committees is judged to be notoriously weak $[46,54,57]$, the improved transparency enables civil society in general to monitor government's progress. Since there are, to date, no sanctions on noncompliance, the possibilities for civil society to hold its government to account are limited to naming and shaming. Local media report substantially on PB processes, and the national ombudsman monitors the implementation at regional level.

\section{CONCLUSIONS}

Participatory budgeting was introduced both in Brazil and in Peru after return to democracy. It was done in the context of a decentralization process which, in turn, substantially increased responsibilities and funding for regional and municipal governments. There are however also a number of important differences. In Brazil, civil society had just gone through a period of strengthening and mobilization while drumming up support for the Constitutional Assembly; in Peru civil society was weak at the moment of PBs introduction. In Brazil, PB was developed "bottom up", at the local level. It was adopted voluntarily by other municipalities and some states. Each locality developed its own PB-rules. In Peru, PB was introduced top-down in the form of national legislation. Negotiations on the procedures needed were also concentrated at national level. The procedures in Porto Alegre allow for a clear phase of direct democracy; there are no formal barriers for citizen's participation and each ordinary citizen can be elected delegate in the PB-process. Peru's PB is characterized by a peculiar mix of direct and representative democracy. There are a number of formal barriers impeding the participation of ordinary citizens, and in all phases also the public sector has an important voice and vote. In Porto Alegre PB was explicitly developed in an attempt to deepen democracy and to develop a "participatory state". In Peru PB was mainly introduced to achieve good governance, and accompanied by a legal framework that strengthened transparency.

Whereas in Porto Alegre participatory budgeting reached ordinary citizens, in Peru it mainly reached the higher echelons of civil society. Many Peruvian civil society leaders were trained, and their organizations strengthened. Brazilian case-studies from cities other than Porto Alegre also reported higher participation and learning effects for CSO-leaders than for ordinary citizens [16-18].

In Peru PB is first and foremost a project at national level. It is promoted by a specific department of national government, in contrast to Porto Alegre where negotiations on the PB-rules take place at national level, with representatives of network organizations and donors. Consequently the most notable effect has been the strengthening of civil society network and capacities at national level. The formation, functioning and impact of the Colectivo Institucional can be considered a clear example of the transformation of civil society as well as a transformation of state-civil society relationships at national level. This has had important off-spring at regional level, and has led to a number of "PB-best practices" at all levels [58].

Despite clear weaknesses, we can also conclude that the introduction of PB offers important opportunities to increase citizens' participation in local decision making, especially where CSO-capacity coincides with political will. Most studies also report slow but sure improvements: an increase in the number of PB-processes, in the quantity and quality of CSO participation, in the level of information provided, and in the perceived quality of the process. PB's implementation and the provision of information has furthermore become part of regular monitoring activities and public scrutiny.

However, the most important difference is that the Peruvian design lacks the autonomous deliberative space created between civil society and the state. In Peru, public sector representatives have an important influence in all steps in the process. Public officials can register as "participating agent", and therewith can take part in the deliberations in the workshops. Almost half of the "participating agents" indeed comes from the public sector. In the CCR/CCL it is even a legal prerequisite that $60 \%$ of the members come from the public sector. We can certainly argue that a new (and so far stable) pattern of state-civil society is currently developing, and therewith thus a new state-society regime. A regime in which openness to societal demands has substantially increased, and the constraints on civil society are low. Yet, in the process of filtering societal demands and collecting civil society's input, the state is 
omnipresent and interfering. Therefore the Peruvian PB shows a lower level of "empowered participation" than its Brazilian example, if we apply Baiocchi’s [10] criteria.

The introduction of participatory mechanism is contentious by its nature. The strengthening of the citizen's voice and his decision making powers means that others both governors and bureaucrats - have to relinquish power. Paraphrasing Holston "Participatory democracy is always becoming and unbecoming. It is not a set stage of institutions, actors, social structures and cultural values; it is never consolidated. As a result its contemporary development is uncertain, both expanding and eroding citizen's voice" (p.78) [36]. We mentioned earlier that PB needs at least two government mandates to mature. Except for the two pioneering cases, the Peruvian PBs have not yet completed this period. Interestingly, in these two pioneering cities PB could build on the political repertoire built up during earlier episodes of participatory governance. The steady progress in PB's implementation and the fact that the new national government has not dared to revert the process indicates that $\mathrm{PB}$ is establishing footholds in Peru's governance system. Even if the sober estimations of only $10 \%$ of the experiments being genuine participatory processes holds true, this still means that at least over 60 Peruvian municipalities foster interesting participatory experiments. Experiments that with their 'footprints' offer potential to gradually strengthen citizens' voice and improve state-civil society relations.

\section{REFERENCES}

[1] Cabannes Y. Les budgets participatifs en Amérique Latine. Mouvements 2006 ; 47: 128-38.

[2] Shah A, Ed. Participatory budgeting. Washington: World Bank 2007.

[3] Sintomer Y, Herzberg C, Rocke A. Participatory budgeting in Europe: potentials and challenges. Int J Urban Reg Res 2008; 32(1): 164-78.

[4] Goldfrank B. Lessons from Latin America's experience with participatory budgeting. In: Shah A, Ed. Participatory budgeting. Washington: World Bank 2007; pp. 91-126.

[5] Abers R. From clientelism to cooperation: local government, participatory policy, and civic organizing in Porto Alegre, Brazil. Polit Soc 1998; 26(4): 511-37.

[6] Abers R. Overcoming the dilemmas of participatory democracy: the participatory budget policy in Brazil. Paper presented at the LASA Conference 2000, Miami: 16-18 March 2000. [Retrieved on 9 March 2009]. Available from: http://www.4shared.com/file/450 42297/942337e7/D4217Overcoming Dilemmas.ht ml?cau2=401w

[7] Baierle S. The explosion of experience: the emergence of a new ethical-political principle in popular movements in Porto Alegre, Brazil. In: Alvarez S, Dagnino E, Escobar A, Eds. Cultures of politics, politics of cultures: revisioning Latin American social movements. Boulder Colorado: Westview Press 1998; pp. 118-38.

[8] Baierle S. Transformation and empowerment through the participatory budget. Logolink international workshop on participatory planning approaches for local governance. Bandung, Indonesia: 20-27 January 2002. [Retrieved on 9 March 2009]. Available from: www2.ids.ac.uk/logolink/resources/downloads/ PPcase_studies/Brazil-CIDADE1.doc

[9] Baierle S. Shoot the Citizen, save the customer. Paper presented ISAcademy Conference. The politics of urban poverty, exclusion and violence: comparative analysis and policy insights. Ministry of Foreign Affairs, The Hague, the Netherlands: 27 \& 28 September 2007. [Retrieved on 9 March 2009]. Available form: http://www.ongcidade.org/site/php/Revista/arquivo/baierleen.pdf

[10] Baiocchi G. Militants and citizens: the politics of participatory democracy in Porto Alegre. Stanford: Stanford University Press 2005 .
[11] Navarro Z. Participatory budgeting in Porto Alegre, Brazil. In: Campbell T, Fuhr H, Eds. Leadership and innovation in subnational government: case studies from Latin America. Washington DC: World Bank 2004.

[12] Wampler B. A guide to participatory budgeting: the international budget project, Center on budget and policy, Washington: World Bank 2000.

[13] Acioly C, Herzog A, Sandino E, Andrade VH. Participatory budgeting in the municipality of Santo André, Brazil: the challenges in linking short-term action and long-term strategic planning. IHS - Institute for Housing and Urban Development Studies, The Netherlands. SINPA - Support to the Implementation of the National Plan of Action / Bolivia Municipality of Santo André, Brazil 2002. [Retrieved on March 9 2009]. Available from: http://siteresources.worldbank.org/INTPCENG/Resources/ENG192 020participatory20budgeting.pdf

[14] Avritzer L. New public spheres in Brazil: local democracy and deliberative politics. Int J Urban Reg Res 2006; 30(3): 623-37.

[15] Baiocchi G. Radicals in power the workers' party (PT) and experiments in urban democracy in Brazil. London: Zedbooks 2003.

[16] Nylen WR. The empowerment thesis: the participatory budget in Belo Horizonte and Betim (Brazil). Comp Polit 2002; 34(2): 12745 .

[17] Monseur S. Political participation and struggle for life in a Brazilian Favela. Master thesis, University of Amsterdam 2007.

[18] Wampler B. Participatory budgeting in Brazil: contestation, cooperation and accountability. Pennsylvania: Pennsylvania State University Press 2007.

[19] Cabannes Y. Participatory budgeting a significant contribution to participatory democracy. Environ Urban 2004; 16(1): 27-46.

[20] Chavez D. Polis \& demos: the left in municipal governance in Montevideo and Porto Alegre. Maastricht: Shaker Publishing 2004.

[21] Goldfrank B. Deepening democracy through citizen participation? A comparative analysis of three cities, paper presented at the 2001 meeting of the Latin American Studies Association, Washington DC, September 6-8, 2001. [Retrieved on 15 March2009]. Available from: http://lasa.international.pitt.edu/Lasa2001/GoldfrankBenja min.pdf

[22] Giddens A. The constitution of society: outline of the theory of structuration. Cambridge: Polity Press 1984.

[23] Long N. The battlefields of knowledge: the interlocking of theory and practice in social research and development. London: Routledge 1992.

[24] Evans P. Development as institutional change: the pitfalls of monocropping and the potentials of deliberation. Stud Comp Int Dev 2004; 38(4): 30-52.

[25] Baiocchi G. Participation, activism, and politics: the Porto Alegre experiment and deliberative democratic theory. Polit Soc 2001; 29(1): 43-72.

[26] Sen A. Development as freedom. New York: Anchor Books 1999.

[27] Novy A, Leubolt B. Participatory budgeting in Porto Alegre: social innovation and the dialectical relationship of state and civil society. Urban Stud 2005; 42(11): 2023-36.

[28] Hordijk MA. Participatory governance in Peru: exercising citizenship. Environ Urban 2005; 17(1): 219-36.

[29] Heller P. Moving the state: the politics of democratic decentralization in Kerala, South Africa, and Porto Alegre. Polit Soc $2001 ; 29(1)$ : 131-63.

[30] Cameron JD. Participatory budgeting in the Andes: between governmentality and hte infrapolis of resistance. Paper presented at the International Studies Association Meeting, 26-29 March 2008, San Francisco. [Retrieved on 9 March 2009]. Available from : http://www.allacademic.com/meta/p_mla_apa_research_citation/2/ 5/1/9/6/p251969 index.html

[31] Heller P. Making citizens from below. In: Bland G, Arnson CJ Eds. Democratic deficits: addressing challenges to sustainability and consolidation around the world. Washington: Latin American Programme Woodrow Wilson International Centre for Scholars 2009; pp. 85-104.

[32] Avritzer L. Democracy and the public sphere in Latin America. Princeton: Princeton University Press 2002.

[33] Salinas Lanao G. Leading to transformation? Participatory budgeting at local level in Ayacucho, Peru. ISS Working Papers 60. The Hague, ISS 2007. 
[34] Cornwall A. Introduction: new democratic spaces? the politics and dynamics of institutionalized participation. IDS Bull 2004; 35(2): $1-10$.

[35] Fung A, Wright E. Deepening democracy: institutional innovations in empowered participatory governance. London: Verso 2003.

[36] Holston J. Citizenship in disjunctive democracies. In: Tulchin JS, Rutherford M, Eds. Citizenship in Latin America. Boulder Colorado: Lynne Rienner 2007; pp. 75-94

[37] Avritzer L. Creating urban reform in Brazil IDS- research summary, IDS, Sussex 2008.

[38] Holston J. Insurgent citizenship, disjunctions of democracy and modernity in Brazil. New Jersey: Princeton University Press 2008.

[39] Dagnino E. Meanings of citizenship in Latin America. IDS Working Paper 258, Sussex, IDS 2005.

[40] Chavez D. The watering down of participation and people's power in Porto Alegre. Participatory Learn Action 2008; 58(1): 57-60.

[41] Harnecker M. Delegating power to the people: participatory budget in Porto Alegre. 1999. [Retrieved on 9 March 2009]. Available from: http://www1.worldbank.org/wbiep/decentralization/laclib/har necker.pdf

[42] Zapata Velasco A. Sociedad y poder local. La comunidad de Villa El Salvador. Lima, Peru, Desco 1996.

[43] Balvin Diaz D, Follegatti JLL, Hordijk MA. Innovative urban environmental management in Ilo, Peru. Environ Urban 1996; 8(1): 21-34.

[44] Follegatti JLL. Ilo: a city in transformation. Environ Urban 1999; 11(2): 181-202.

[45] Oxhorn P. Neopluralism and citizenship in Latin America. In: Tulchin JS, Ruthenburg M, Eds. Citizenship in Latin America. Boulder Colorado: Lynne Rienner 2007; pp 123-48.

[46] Chirinos L. Civil society and successful accountability in Peru. In: Bland G, Arnson CJ, Eds. Democratic deficits: Addressing challenges to sustainability and consolidation around the World. Washington: Latin American Programme Woodrow Wilson International Centre for Scholars 2009; pp. 105-33.

[47] Miranda SL, Hordijk MA. Let us build cities for life: the national campaign of Local Agenda 21s in Peru. Environ Urban 1998; 10(2): 69-102.

[48] Grompone R. Discutiendo la intervención ciudadana en el presupuesto participativo regional. Cuadernos Descentralistas 73 . Lima: Grupo Propuesta Ciudadana-Oxfam 2005.

[49] McClintock C. An unlikely comeback in Peru. J Democr 2006; 17(4): 95-109.

[50] Baca E, Ccoyllo JJ, Muñoz A, Vidal C. Grupo Propuesta Ciudadana, Participa Perú - Por el País que soñamos. Lima: Vigila Perú 2008; (42): 1-16.

[51] MEF - DNNP El Presupuesto Participativo en el Peru: Lecciones aprendidas y desafíos, Lima 2005. [Retrieved 9 March 2009]. Available from: http://www.mef.gob.pe/DNPP/documentos/5p_ PPartic ipativoenelPeru.pdf

[52] Chirinos L. Participación ciudadana en los gobiernos regionales: el caso de los consejos de coordinación local regional. In: Grupo Propuesta Ciudadana La participación ciudadana y la construcción de la democracia en América Latina. Grupo Propuesta Ciudadana. Lima: Oxfam 2005.

[53] Monge C. Participatory budgets: the Peruvian experience. Paper presented at the World Bank Conference on local development Washington DC. June 2-4, 2004. [Retrieved 9 March 2009]. Available from: http://www1.worldbank.org/sp/ldconference/ Materials/Parallel/PS1/PS1 S5 PPT3.pdf

[54] CIPP Presupuesto Participativo: agenda pendiente: Balance, lecciones aprendidas y recomendaciones, Lima, Colectivo Interinstitucional del Presupuesto Participativo. [Retrieved on 9 March 2009]. Available from: http://www.participaperu.org.pe/apcaa/archivos-aa/068d5099c088d67686280321657b29ee/_20_Presu puesto_Particpativo__Agenda_Pendiente.pdf

[55] Konstantakos S. Participatory budgeting in San Juan de Miraflores, Lima, Peru: implications for participatory governance. Master thesis, University of Amsterdam 2006

[56] Llona M. Presupuesto participativo: alcances y limites de una politica publica. Paper presented at the Conference evaluación, democracia y gobernabilidad: desafíos para America Latina, 20-22 October 2004. [Retrieved on 9 March 2009]. Available from: http://desco.cepes.org.pe/apc-aa-files/d38fb34df77ec8a36839f7aad 10def69/mariana_llona15.doc

[57] MCLCP Primer Informe Nacional de Monitoreo: resultados del proceso participativo. Lima, Mesa de concertación para la lucha contra la pobreza 2007. [Retrieved on 9 March 2009]. Available from: http://www.mesadeconcertacion.org.pe/contenido.php?pid= 87

[58] CIPP Foro de Experiencias de presupuesto participativo premiación del concurso de experiencias exitosas de presupuesto participativo. Lima 2006. [Retrieved on 9 March 2009]. Available from: http://www.mesadeconcertacion.org.pe/documentos/general/ gen 00678.pdf

[59] El Peruano 380349. [Retrieved 9 March 2009]. Available from: http://www.mef.gob.pe/DNPP/comunicados/comunicado018 2008 EF7601.pdf

[60] Arroyo J. La democracia municipal en la descentralización peruana 2001-2005: ¿exceso o insuficiencia de la participación? Revista del CLAD Reforma y Democracia 2006; 36 Caracas. [Retrieved 9 March 2009]. Available from: http://www.clad.org.ve/portal/ publica ciones-del-clad/revista-clad-reforma-democracia/articulos/ 036-octu bre-2006/0054600

[61] Defensoría del Pueblo. Análisis y aportes sobre el presupuesto participativo. Lima: Defensoría del Pueblo 2005.

[62] Conterno E. Potenciando la participación en el Peru: presupuesto participativo y consejos de coordinación. [Retrieved on 9 March 2009]. Available from: http://www.lasociedadcivil.org/docs/cibert eca/e conterno.pdf

[63] Defensoria del Pueblo. Cuarto reporte y balance anual 2008 de la supervisión de los portales de transparencia de los gobiernos regionales y de las municipalidades provinciales ubicadas en capitales de departamentos. Lima: Defensoria del Pueblo 2009.

[64] Latinobarometro. Informe de Prensa 2006. [Retrieved 9 March 2009]. Available from: http://www.globalexchange.org/countries/ amer icas/venezuela/Latinobarometro.pdf

(C) M.A. Hordijk; Licensee Bentham Open.

This is an open access article licensed under the terms of the Creative Commons Attribution Non-Commercial License (http://creativecommons.org/licenses/by$\mathrm{nc} / 3.0 /$ ) which permits unrestricted, non-commercial use, distribution and reproduction in any medium, provided the work is properly cited. 